\title{
Zasady dopuszczeń pojazdów kolejowych w ruchu międzynarodowym po wejściu w życie dyrektyw II pakietu kolejowego
}

\begin{abstract}
$W$ artykule przedstawiono informacje na temat stanu opracowania procedur zwiazanych $z$ dopuszczeniem pojazdów kolejowych, po wprowadzeniu w życie dyrektywy II pakietu kolejowego. Prace te sq wynikiem inicjatyw Unii Europejskiej podejmowanych w celu zwiększania konkurencyjności kolei. W artykule zostały wymienione $i$ opisane różnego rodzaju dokumenty, przyjęte już do stosowania przez państwa Uni lub krajowe, obowiqzujace $w$ Polsce, oraz robocze, opracowane przez grupe specjalna (Task Force) powolana przez Dyrektoriat Generalny Energii i Transportu. Niektóre istotne dokumenty zostaty zacytowane we fragmentach. We wniosku stwierdzono, że przewidywane procedury i zwiazane z nimi regulacje techniczne nie będq zagrożeniem dla polskich przewoźników planujacych obstuge ruchu międzynarodowego.
\end{abstract}

\section{Wstęp}

Mimo intensywnych prac Unii Europejskiej dla zwiększenia konkurencyjności kolei $\mathrm{w}$ transporcie na naszym kontynencie, których efektem jest opracowanie i wprowadzenia szeregu dyrektyw i przepisów wykonawczych do nich, praktyczne ich wdrażanie napotyka na wiele trudności. Kluczowym zagadnieniem dla faktycznego wdrożenia interoperacyjności taboru kolejowego jest uzgodnienie zasad i procedur wzajemnego dopuszczania lokomotyw. Niniejszy artykuł przedstawia podstawowe informacje o stanie aktualnym procesu umożliwiającego przekraczania granic państwowych przez lokomotywy.

\section{Dyrektywy II pakietu kolejowego}

Akty prawne wydawane przez Parlament Europejski i Radę Unii Europejskiej dotyczące kolejnictwa podzielone zostały na tzw. pakiety $[12,13]$. Drugi pakiet kolejowy pochodzi z 30.04.2004 roku (Official Journal of the European Union - L164) i obejmuje następujące trzy dyrektywy oraz rozporządzenie:

- Dyrektywa 2004/51 [1]

- Dyrektywa 2004/50 [2]

- Dyrektywa 2004/49 [3]

- Rozporządzenie [4]. Ten dokument nie wymaga implementacji do prawodawstwa polskiego, ponieważ obowiązuje wprost.

Dyrektywa [1] została transponowana w przyjętej przez Sejm RP ustawie o zmianie ustawy o transporcie kolejowym oraz o zmianie innych ustaw, a jej tekst jednolity został opublikowany w Obwieszczeniu Marszałka Sejmu RP z dnia 19 stycznia 2007 r. [5]. Z kolei Dyrektywa wymieniona w [2] znalazła swoje odbicie w Rozporządzeniu Ministra Transportu z dnia 5 września 2006 r. [6]. Ponadto w Polsce obowiazzuje Rozporządzenie Ministra Infrastruktury z 12.10.2005 r. [7] dotyczące zakresu badań koniecznych do uzyskania świadectw dopuszczenia do eksploatacji.
Dokumenty normatywne, które powinny być uwzględnione przy projektowaniu i w procedurach badawczych zostały ujęte w Obwieszczeniu Prezesa Urzędu Transportu Kolejowego z dnia 8 sierpnia 2005 r. w sprawie ustalenia listy właściwych krajowych specyfikacji technicznych i dokumentów normalizacyjnych, których zastosowanie umożliwi spełnienie zasadniczych wymagań dotyczących interoperacyjności kolei [8].

W Rozporządzeniu [6] została przywołana Decyzja Komisji z dnia 23 grudnia 2005 r. dotyczaca technicznej specyfikacji dla interoperacyjności odnoszącej się do podsystemu ,tabor kolejowy - hałas” transeuropejskiego systemu kolei konwencjonalnych [9] ustanawiająca Techniczną Specyfikację dla Interoperacyjności dla taboru kolejowego. Ponadto w Unii Europejskiej obowiązuje już akt prawny, który nie został jeszcze przywołany w żadnym akcie prawnym wprowadzonym w Polsce, dotyczący TSI dla wagonów towarowych systemu kolei konwencjonalnych, a mianowicie Decyzja Komisji z dnia 28 lipca 2006 r. dotycząca technicznej specyfikacji dla interoperacyjności odnoszącej się do podsystemu „tabor kolejowy - wagony towarowe" transeuropejskiego systemu kolei konwencjonalnych [10].

Dla zagadnienia dopuszczeń pojazdów kolejowych istotnymi dokumentami są [3], [5] oraz [7] i te właśnie zostały uwzględnione w dalszym opisie zagadnień będących tematem artykułu.

\section{Dokumenty robocze Dyrektoriatu Generalnego Energii i Transportu}

Poza wymienionymi w pkt. 2 istotne dla tematu są następujące dokumenty firmowane przez Dyrektoriat Generalny ds. Energii i Transportu Komisji Europejskiej, dostępne (częściowo w języku polskim) na oficjalnej stronie internetowej Komisji Europejskiej Transport w dziale Rail Transport i Interoperability Safety, przywołane w raporcie [11]. 
a) Press release: European Commision proposes new measures to remove red tape hindering the development of railways throughtout Europe (bez sygnatur)

b) Memo: Towards an integrated European railway area (bez sygnatur)

c) Komunikat Komisji do Rady i Parlamentu Europejskiego: Ulatwienie przemieszczania się lokomotyw na obszarze Wspólnoty. Bruksela, 13.12. 2006. $\mathrm{KOM}(2006)$ 782; wersja ostateczna

d) Wniosek do: Dyrektywa Parlamentu Europejskiego i Rady $w$ sprawie interoperacyjności wspólnotowego systemu kolei. Bruksela, 13.12. 2006 r. COM(2006) 783; wersja ostateczna

e) Wniosek do: Dyrektywa Parlamentu Europejskiego i Rady zmieniająca dyrektywę 2004/49/ WE w sprawie bezpieczeństwa kolei wspólnotowych. Bruksela, 13.12.2006. $\mathrm{KOM}(2006)$ 784; wersja ostateczna

f) Proposal for a Regulation of the European Parliament and of the Council amending Regulation (EC) No 881/2004 establishing a European Railway Agency. Brussels, 13.12.2006. COM(2006) 785; final

g) Commission Staff Working Document. Annex to the Communication from the Com-mission to the Council and the European Parliament. Facilitate free movement of locomotives across the EU. Brussels, 13.12.2006. SEC(2006) 1640

h) Commission Staff Working Document accompanying the Communication from the Commission to the Council and the European Parliament. Facilitate interoperability of locomotives across the EU. Brussels, 13.12.2006. SEC (2006) 1641

i) Dokument roboczy Komisji. Dokument towarzyszący do Komunikatu Komisji dla Rady i Parlamentu Europejskiego Ulatwienie przemieszczania się lokomotyw na obszarze Wspólnoty Bruksela, 13.12. 2006. SEC(2006) 1642.
Ze względu na trudności w rozwiązywaniu zagadnień dotyczących wzajemnego uznawania taboru przez państwa członkowskie Unii Europejskiej, Komisja Europejska powołała w 2005 r. Grupę Specjalną (Task Force), która z mandatu Dyrektoriatu Generalnego ds. Energii i Transportu Komisji Europejskiej opracowała kilka dokumentów, między innymi:

j) Guideline For Cross Acceptance of Rolling Stock. Task Force for Cross Acceptance of Rolling Stock. Draft. 5.12.2005

k) Consultation Document: Improving Cross Acceptance of Rolling Stock: problems, objectives and options. Brussels 12.04.2006

1) Annexes (do Listy kontrolnej) przywołanej w pkt. 2.j) wg poniższego wykazu:

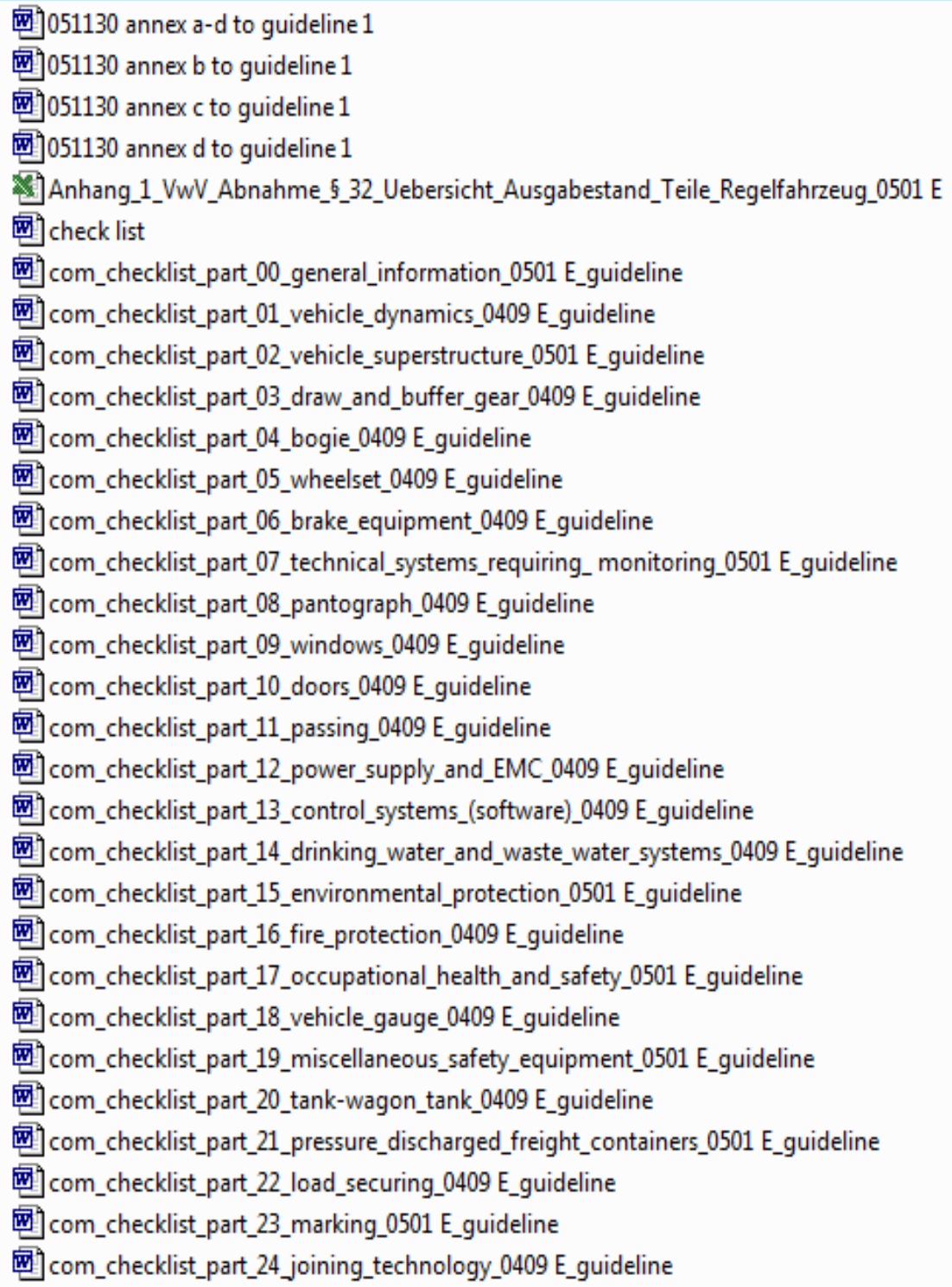


,...Artykut 14

Dopuszczanie do eksploatacji użytkowanego taboru kolejowego

1. Tabor kolejowy, na który wydano zezwolenie na dopuszczenie do eksploatacji w jednym Państwie Członkowskim stosownie do art. 10 ust. 2 lit. b), a który nie w petni jest objęty stosownymi TSI, musi uzyskać zezwolenie na dopuszczenie do eksploatacji w innym Państwie Członkowskim lub w innych Państwach Członkowskich stosownie do niniejszego artykutu, jeżeli uzyskanie takiego zezwolenia jest wymagane przez takie Państwo Członkowskie lub przez takie Państwa Członkowskie.

2. Przedsiębiorstwo kolejowe wnioskujace o zezwolenie na dopuszczenie taboru do eksploatacji $w$ innym Państwie Członkowskim przedstawia odpowiedniej władzy bezpieczeństwa zestaw dokumentacji technicznej dotyczacej taboru kolejowego lub typu taboru kolejowego, opisujac jego planowane zastosowanie w sieci. Zestaw dokumentacji zawiera nastepujace informacje:

a) dowody uzyskania zezwolenia na dopuszczenie taboru do eksploatacji w innym Państwie Członkowskim wraz z rejestrami zawierajacymi historie eksploatacji, utrzymania oraz, jeśli to właściwe, modyfikacji technicznych dokonanych po uzyskaniu zezwolenia;

b) stosowne dane techniczne, plany utrzymania $i$ charakterystyki operacyjne wymagane przez wtadze bezpieczeństwa dla potrzeb zezwolenia uzupetniajacego,

c) dowody zgodności charakterystyki technicznej $i$ operacyjnej taboru kolejowego z systemem zasilania $w$ energie, systemem sygnalizacji oraz nadzoru sterowania, szerokościa torów i skrajniami infrastruktury, maksymalnym dopuszczalnym obciażeniem osi i innymi ograniczeniami sieci;

d) informację o wyjatkach od krajowych przepisów bezpieczeństwa, które sq niezbędne do udzielenia zezwolenia, oraz dowody, oparte na ocenie ryzyka, potwierdzajace, iz dopuszczenie do eksploatacji taboru kolejowego nie wprowadzi większych niż dopuszczalne ryzyk $w$ sieci.

3. Wtadza bezpieczeństwa może wymagać wykonania jazd próbnych $w$ sieci $w$ celu weryfikacji zgodności z ograniczeniami wymienionymi w ust. 2 lit. c) $i$ w tym wypadku powinna określić ich zakres $i$ co ma się na nie sktadać. ..."

Istotny dla zagadnienia dopuszczeń pojazdów kolejowych do ruchu międzynarodowego jest rozdz. 4a Ustawy o transporcie kolejowym [5], a zwłaszcza jej art. 25d, wprowadzony zmianą 20.04.2004 r., który ma zastosowanie w przypadku, gdy TSI jeszcze nie zostały ogłoszone.
„... 1. W przypadku, gdy TSI nie zostaty ogłoszone przez Komisje Europejska, Prezes UTK ustala liste właściwych krajowych specyfikacji technicznych $i$ dokumentów normalizacyjnych, których zastosowanie umożliwi spetnienie zasadniczych wymagań dotyczacych interoperacyjności kolei.

2. Listę, o której mowa w ust. 1, ogłasza się, w drodze obwieszczenia, $w$ dzienniku urzędowym ministra właściwego do spraw transportu.

3. Prezes UTK przekazuje listę, o której mowa w ust. 1, Komisji Europejskiej i właściwym organom państw członkowskich Unii Europejskiej. ..."

Według aktualnego stanu ma to miejsce w odniesieniu do pojazdów trakcyjnych (lokomotyw i e.z.t.) i wagonów pasażerskich. Dla tych pojazdów konieczne jest ogłoszenie przez Prezesa UTK listy specyfikacji technicznych i dokumentów normalizacyjnych. Lista ta jest listą publiczną i powinna być przekazana do wiadomości Komisji Europejskiej i właściwym organom państw członkowskich Unii Europejskiej. Dla wagonów towarowych obowiązujące są ogłoszone już TSI.

W odniesieniu do zakresu (listy) niezbędnych dokumentacji i badań dla oceny zgodności pojazdu z infrastrukturą istotne są uregulowania zawarte w art. 23 ust. 2, 2a i 2b ww. Ustawy.

2. Pojazdy kolejowe należqce do zagranicznych przewoźników kolejowych dopuszcza się do eksploatacji na terytorium Rzeczypospolitej Polskiej, jeżeli zostaty dopuszczone do eksploatacji w komunikacji międzynarodowej w kraju ich właścicieli oraz spetniaja warunki techniczne określone $w$ przepisach wydanych na podstawie art. 20.

2a. Na pojazdy kolejowe, na które wydano świadectwo dopuszczenia do eksploatacji typu pojazdu kolejowego $w$ innym państwie czlonkowskim Unii Europejskiej w sieciowej części certyfikatu bezpieczeństwa, o której mowa w art. 18 b ust. 1 pkt 2, które nie sa $w$ petni objęte TSI, należy uzyskać świadectwo dopuszczenia do eksploatacji typu pojazdu kolejowego, jeżeli świadectwo takie jest wymagane.

2b. Prezes UTK wydaje przewoźnikowi kolejowemu z innego państwa członkowskiego Unii Europejskiej świadectwo dopuszczenia do eksploatacji typu pojazdu kolejowego po przedstawieniu zestawu dokumentacji technicznej zawierajacej:

1) świadectwa dopuszczenia do eksploatacji typu pojazdu kolejowego lub zezwolenia wydane w innym państwie członkowskim Unii Europejskiej wraz z dokumentacja zawierajaca przebieg eksploatacji i utrzymania oraz modernizacji pojazdów kolejowych, w przypadku gdy modernizacja nastapiła po uzyskaniu świadectwa lub zezwolenia; 
2) dane techniczne, plany utrzymania, dokumentacje techniczno-ruchowa $i$ inne charakterystyki ruchowe;

3) dowody zgodności charakterystyki technicznej i operacyjnej pojazdów kolejowych z systemem zasilania $w$ energie, systemem sterowania ruchem kolejowym i sygnalizacji, szerokościq torów, skrajniami budowli, maksymalnym dopuszczalnym naciskiem osi i innymi ograniczeniami sieci kolejowej;

4) informacje o odstepstwach od krajowych przepisów bezpieczeństwa, niezbędne do wydania świadectwa, oraz dowody oparte na ocenie ryzyka potwierdzajace, że dopuszczenie pojazdów kolejowych do eksploatacji nie przekroczy dopuszczalnych zakłóceń $w$ sieci kolejowej. ..."

Istotną nową regulacją wprowadzoną zmianą ustawy, jest obowiązek prowadzenia rejestru taboru przez przewoźnika kolejowego lub inny podmiot eksploatujący pojazdy kolejowe. Kopie rejestrów Prezes UTK przekazuje zainteresowanym państwom Unii Europejskiej oraz Europejskiej Agencji Kolejowej.

\section{Działania Komisji Europejskiej}

Komisja Europejska przyjęła szereg środków dla wsparcia rewitalizacji sektora kolejowego przez usunięcie przeszkód w przemieszczaniu się pociągów w europejskiej sieci kolejowej (patrz: European Commission - Rail Transport and Interoperability - Safety Cross-acceptance). Część tych środków dotyczy uproszczenia certyfikowania pojazdów kolejowych, propozycji przetworzenia istniejących Dyrektyw dotyczących interoperacyjności kolei i modyfikacji rozporządzenia ustanawiającego Europejską Agencję Kolejową oraz Dyrektywy dotyczące bezpieczeństwa kolei. Ze względu na to, że integrowanie transportu kolejowego w Unii dotyka skomplikowanej materii bezpieczeństwa przygotowano szereg dokumentów.

$\mathrm{W}$ dokumencie podanym w pkt. 2.c) szczegółowo opisano trudności, na jakie napotyka tworzenie jednolitej, dostępnej europejskiej sieci kolei konwencjonalnej. Zalecaną zasadą wg tego dokumentu powinna być zasada wzajemnego uznawania.

Proponowane kierunki działania dla różnego typu taboru są zróżnicowane. W pkt. 2.1 tego dokumentu omówiono stan dla dwóch rodzajów taboru: trakcyjnego i wagonów.

„... W zakresie dotyczqcym lokomotyw $i$ zespotów trakcyjnych $w$ celu uzyskania zgody na dopuszczenie do eksploatacji w innym państwie członkowskim należy wykazać, że eksploatowane lokomotywy pozostaja $w$ zgodzie z krajowymi przepisami tego państwa członkowskiego. Przepisy krajowe zawieraja specyfikacje $i$ normy dotyczqce kompatybilności infrastruktury, a także szczególne krajowe wymagania dotyczqce bezpieczeństwa.
Infrastruktura kolejowa na terenie państw członkowskich posiada zróżnicowane parametry, takie jak rozstaw infrastruktury, właściwości zaktóceń elektromagnetycznych, napięcia energii dostarczanej do linii trakcyjnej oraz systemy kontroli i sterowania. Szczególne wymagania krajowe dotyczace bezpieczeństwa maja swoja podstawe w krajowych wymaganiach technicznych, a także odzwierciedlaja wnioski wyciagnięte $z$ wypadków $i$ zdarzeń, do których doszło $w$ poszczególnych państwach czlonkowskich.

Ostatnie badania wykazaty, że we wszystkich państwach członkowskich istnieja takie same zasady bezpieczeństwa, na przyktad w zakresie tylnych oznaczeń pojazdów, zasad bezpieczeństwa pożarowego $w$ taborze kolejowym, dziatania drzwi dla pasażerów, światet awaryjnych itp. Jednakże szczegółowe kryteria krajowe stużace wykazaniu, że zasady te sa przestrzegane, istotnie sie różniq. Niemniej jednak poziom bezpieczeństwa kolejowego nie różni się zbytnio pomiędzy państwami członkowskimi, pokazujac, że podejście do kwestii bezpieczeństwa jest porównywalne w poszczególnych kolejach krajowych.

W niektórych państwach czlonkowskich zasady bezpieczeństwa i normy techniczne sq wciaż ksztaltowane i sq $w$ trakcie określania, dokumentowania i publikowania, zgodnie z postanowieniami dyrektyw w sprawie interoperacyjności kolejowej $i$ bezpieczeństwa. Jednak wstępna ocena tych zasad ukazuje znaczne różnice $w$ zakresie rozumienia tego, czym sq krajowe zasady bezpieczeństwa, przy jednoczesnym braku notyfikacji tych zasad z wielu powodów, na przykład dlatego, że przyjmuje się, iz zasady te sq objęte TSI. W rezultacie nadal brakuje petnej przejrzystości wśród kolei krajowych $w$ UE $w$ zakresie obowiazujacych zasad krajowych dotyczacych dopuszczania taboru kolejowego do eksploatacji. Sytuacja ta tworzy dla producentów $i$ przedsiębiorstw kolejowych dodatkowe problemy $w$ momencie występowania o dopuszczenie nowego lub eksploatowanego już taboru kolejowego, ponieważ ponoszq one ryzyko spóźnionego uwzględnienia szczególnych wymogów krajowych przy projektowaniu pojazdów, co powoduje opóźnienia lub zwiększa koszty wprowadzenia taboru kolejowego do eksploatacji.

$W$ odniesieniu do wagonów towarowych $i$ pasażerskich istniejace porozumienia, takie jak RIC i RIV, zapewnity wzajemne dopuszczanie do eksploatacji pod warunkiem uwzględnienia szeregu warunków, z których jednym jest rejestracja wagonów towarowych $i$ pasażerskich u członków UIC, którzy w zamian biora na siebie utrzymanie taboru kolejowego. $Z$ chwila wdrożenia dyrektyw europejskich $w$ sprawie interoperacyjności $i$ bezpieczeństwa postanowienia RIV/RIC zostana częściowo zastapione przez postanowienia UE, zaś częściowo przez nowa umowe GCU. Do czasu przyjęcia wszystkich TSI, ustanowienia rejestrów dotyczacych infrastruktury $i$ taboru kolejowego, ustanowienia krajowych władz do spraw bezpieczeństwa, 
które będq uprawnione do dopuszczania taboru kolejowego do eksploatacji, tacznie z rejestracja, i do czasu, gdy państwa członkowskie w petni wdroża dyrektywy $w$ sprawie interoperacyjności $i$ bezpieczeństwa, znajdujemy się w okresie przejściowym. Bardzo ważne jest, aby wszyscy uczestnicy znali zakres swoich obowiazków i znali postanowienia, które musza stosować $w$ trakcie tego okresu przejściowego. Dlatego też Komisja po konsultacji z wszystkimi zainteresowanymi uczestnikami i państwami czlonkowskimi opracowata „przewodnik dla okresu przejściowego". Zasada wzajemnego zatwierdzania istniejacych wagonów towarowych/wagonów pasażerskich z oznaczeniem RIV/RIC jest już uznawana. ..."

W pkt. 3.2 tego samego dokumentu stwierdza się, że: „...Zalecane jest stosowanie przez wszystkie państwa czlonkowskie wspólnej listy kontrolnej (załacznik $V^{2)}$ ) do projektów zwiqzanych z dopuszczaniem do eksploatacji na zasadzie wzajemności.

Państwa czlonkowskie powinny przedstawić zestawienie wymagań na podstawie listy kontrolnej $i$ wytycznych zawartych w załaczniku VI. Zachęca się również państwa czlonkowskie do stosowania tych wytycznych do bieżacych projektów zarówno w ujęciu dwustronnym, jak $i$ wielostronnym. ..."

Wyżej cytowany we fragmentach dokument odwołuje się także do dokumentu z pkt. 2.g), a zwłaszcza do jego kilku załączników:

II - procedury przekazywania do eksploatacji,

IV - zasada wzajemnego uznawania,

$\mathrm{V}$ - lista parametrów,

VI - przewodnik homologowania już użytkowanego taboru kolejowego.

Lista parametrów odnosząca się do taboru (oparta na dokumentach stosowanych przez niemiecki urząd EBA), podlegających ocenie $\mathrm{w}$ trybie wzajemnego uznawania, jest następująca:

0 . informacje ogólne

1. dynamika pojazdu

2. struktura pojazdu

3. urządzenie pociagowe i zderzaki

4. wózek i urządzenia biegowe

5. zestaw kołowy / łożyskowanie zestawu kołowego

6. wyposażenie hamulca

7. systemy techniczne wymagające monitoringu np. system sprężonego powietrza

8. okna czołowe / boczne

9. drzwi

10. urządzenia przejścia

11. systemy sterowania (software)

12. woda pitna, systemy wody zużytej

13. ochrona środowiska

2) - przypisek autora: dotyczy załaczników do dokumentu przytoczonego $w$ pkt. $3 \mathrm{~g}$ )
14. ochrona przeciwpożarowa

15. bezpieczeństwo i higiena pracy

16. zbiorniki cystern

17. odprężanie ciśnienia wagonów zbiornikowych

18. zabezpieczenie ładunku

19. oznakowanie

20. technologia łączenia.

Ostatni z załączników przywołuje trzy grupy dokumentów:

A - zawiera normy międzynarodowe

B - zawiera wymagania krajowe, które mogłyby być dopasowane do wzajemnego uznawania

$\mathrm{C}$ - zawiera niepodważalne wymagania powiązane $\mathrm{z}$ charakterystykami technicznymi infrastruktury w poszczególnych krajach lub sieciach (podobnie jak rozdziale „Przypadki szczególne” w TSI).

Od 2005 r. działa powołana przez Komisję Europejską Grupa Specjalna do sprawy wzajemnego uznawania taboru. Dostępne dokumenty wyliczone w pkt. 2.j), 2.k) i 2.1) opracowane przez Grupę są dokumentami roboczymi, ale wskazuja realne kierunki poszukiwań rozwiązania problemu.

Grupa Specjalna dokonała następujących ustaleń (pkt. 5a w dokumencie przytoczonym w pkt. 2.j):

. Pojazdy (lub ich części) dopuszczone na mocy TSI, RIC-RIV i COTIF sq z zasady wzajemnie akceptowane. Grupa Specjalna usilnie rekomenduje stosowanie wspólnej listy kontrolnej (Zat. C) do projektów wzajemnego dopuszczania przez wszystkie Państwa Członkowskie. Struktura wspólnej listy kontrolnej nie powinna być zmieniana. Wspólna lista kontrolna powinna zawierać wszystkie odpowiednie przepisy każdego Państwa Członkowskiego.

Wymagania co do akceptowania zgodnie ze wspólna lista kontrolnq sq podzielone na trzy grupy: $A, B, C$. ..."

Kategorie te zostały opisane już wyżej.

Porównanie listy kontrolnej z zakresem badań wymaganych przez [7] prowadzi do wniosku, że brak między tymi listami pełnej zgodności, a ponadto wykaz badań koniecznych wymienionych w Rozporządzeniu nie zawiera żadnych odniesień do dokumentów normalizacyjnych.

W przypadku wykazania dwustronnie dobrej woli, możliwe jest zawarcie odpowiednich porozumień wprowadzających zasadę międzynarodowego wzajemnego dopuszczania do eksploatacji taboru kolejowego. Przykładem może tutaj być porozumienie podpisane $\mathrm{w}$ 2006 r. między EBA i departamentem francuskiego Ministerstwa Transportu lub w sprawie korytarza Rotterdam - Genua.

Grupa Robocza proponuje, jak wspomniano wyżej, stosowanie jednolitej, tzw. listy kontrolnej podzielonej na zagadnienia wymienione wcześniej, po ich uzupełnieniu o: 
- poz. 8: pantograf

- poz. 12: zasilanie energią elektryczną / kompatybilność elektromagnetyczna

- poz. 18: skrajnia pojazdu

- poz. 19: różne wyposażenie bezpieczeństwa (np. sterowania ruchem, radio pociagowe).

Do każdej części tzw. listy kontrolnej (patrz pkt. 2.k), podzielonej na odpowiednie grupy tematyczne, wprowadzono zestawienie konkretnych dokumentów normatywnych. Dodatkowo, w porównaniu do oficjalnego dokumentu EBA, na którym oparto listę kontrolną, wprowadzono podział przywołanych dokumentów normalizacyjnych na międzynarodowe i krajowe. W aktualnym stanie tej listy wypełnione są tylko kolumny z dokumentami międzynarodowymi.

Możliwe opcje dochodzenia do wspólnego rozwiązania docelowego opisano w pkt. 5.1 dokumentu przywołanym w pkt. 2.1) i w załączniku III.

\section{Wnioski}

Mając na uwadze:

- $\quad$ stanowisko Zespołu PKP ds. Interoperacyjności (szczegóły w kolejnych raportach - praca CNTK 4016/12) odnośnie wdrażania TSI dla wagonów towarowych [14]

- konsekwentne stosowanie w Polsce międzynarodowych standardów (EN, kart UIC) w dotychczasowej praktyce projektowania, modernizowania i badania lokomotyw

można stwierdzić brak, w odniesieniu do techniki, istotnych zagrożeń wynikających z aktualnego stanu aktów prawnych dotyczących dopuszczeń pojazdów kolejowych do ruchu międzygranicznego dla polskich przewoźników kolejowych.

\section{Literatura}

[1] Dyrektywa 2004/51 zmieniajaca dyrektywę Rady 91/440/EWG w sprawie rozwoju kolei wspólnotowych

[2] Dyrektywa 2004/50 zmieniajaca dyrektywę Rady 96/48/WE w sprawie interoperacyjności transeuro-pejskiego systemu kolei dużych prędkości i dyrektywę 2001/16/WE Parlamentu Europejskiego $i$ Rady w sprawie interoperacyjności transeuropejskiego systemu kolei konwencjonalnej

[3] Dyrektywa 2004/49 w sprawie bezpieczeństwa kolei wspólnotowych oraz zmieniajaca dyrektywe Rady 95/18/WE w sprawie przyznawania licencji przed-siębiorstwom kolejowym, oraz dyrektywe 2001/14/WE w sprawie alokacji zdolności przepustowej infrastruktury kolejowej $i$ pobierania opłat za uzytkowanie infrastruktury kolejowej oraz certyfikacje $w$ zakresie bezpieczeństwa

[4] Rozporzadzenie 881/2004 ustanawiajace Europejska Agencję Kolejowa
[5] Obwieszczenie Marszatka Sejmu RP z dnia 19 stycznia 2007 r. w sprawie ogłoszenia jednolitego tekstu ustawy o transporcie kolejowym (z 28 marca 2003 r. z późniejszymi zmianami: 20.04.2004, 16.12.2005 i 22.07.2006)

[6] Rozporzadzenie Ministra Transportu z dnia 5 września 2006 r. w sprawie zasadniczych wymagań dotyczacych interoperacyjności kolei oraz procedur oceny zgod-ności dla transeuropejskiego systemu kolei konwencjonalnych

[7] Rozporzadzenie Ministra Infrastruktury z 12.10.2005 r. w sprawie zakresu badań koniecznych do uzyskania świadectw dopuszczenia do eksploatacji typów budowli $i$ urzadzeń przeznaczonych do prowadzenia ruchu kolejowego oraz typów pojazdów kolejowych

[8] Obwieszczenie Prezesa Urzędu Transportu Kolejo-wego z dnia 8 sierpnia 2005 r. w sprawie ustalenia listy właściwych krajowych specyfikacji technicznych $i$ dokumentów normalizacyjnych, których zastosowanie umożliwi spetnienie zasadniczych wymagań dotyczacych interoperacyjności kolei

[9] Decyzja Komisji z dnia 23 grudnia 2005 r. dotyczaca technicznej specyfikacji dla interoperacyjności odno-szacej się do podsystemu ,tabor kolejowy - hatas" transeuropejskiego systemu kolei konwencjonalnych

[10] Decyzja Komisji z dnia 28 lipca 2006 r. dotyczqca technicznej specyfikacji dla interoperacyjności odnoszacej się do podsystemu ,tabor kolejowy wagony towarowe" transeuropejskiego systemu kolei konwencjonalnych

[11] Cross-Acceptance propo-sals adopted on $13 \mathrm{De}$ cember 2006. (http://ec.europa.eu/transport/rail/ safety/cross-acceptance_en.htm)

[12] Schweinberg R., Fischer K.: Die europäische Entwicklung im Eisenbahnbereich - Chance für den Güterverkehr. Eisenbahntechnische Rundschau. 2005 nr 7-8

[13] Burnewicz J.: Rynki transportowe UE w Strategii Lizbońskiej - liberalizacja i integracja. Polskie forum strategii lizbońskiej. Instytut Badań nad Gospodarka Rynkowa (http://www.pfsl.pl/ news.php?id=153)

[14] Bieżaca analiza europejskich prac nad technicznymi specyfikacjami dla interoperacyjności systemu trans-europejskich kolei konwencjonalnych. Temat CNTK 4016 (raporty kwartalne 01 $\div$ 12) 